\title{
ANIMAL RESEARCH PAPER Effects of xylanase supplementation on feed intake, digestibility and ruminal fermentation in Rambouillet sheep
}

\author{
L. H. VALLEJO ${ }^{1}$, A. Z. M. SALEM ${ }^{1}$, L. M. CAMACHO ${ }^{2}$, A. M. KHOLIF ${ }^{3}$, M. D. MARIEZCURRENA ${ }^{4}$, \\ M. CIPRIANO ${ }^{2}$, M. U. ALONSO ${ }^{1}$, J. OLIVARES ${ }^{2}$ AND S. LOPEZ ${ }^{5}$ \\ ${ }^{1}$ Facultad de Medicina Veterinaria y Zootecnia, Universidad Autónoma del Estado de México, Toluca, México \\ ${ }^{2}$ Unidad Académica de Medicina Veterinaria y Zootecnia, Universidad Autónoma de Guerrero, Cd. Altamirano-Iguala, \\ Guerrero, México \\ ${ }^{3}$ Dairy Science Department, National Research Centre, 33 Bohouth St. Dokki, Giza, Egypt \\ ${ }^{4}$ Facultad de Ciencias Agrícola, Universidad Autónoma del Estado de México, Toluca, México \\ ${ }^{5}$ Instituto de Ganadería de Montaña (IGM) CSIC-Universidad de León, Departamento de Producción Animal, \\ Universidad de León, E-24071 León, Spain
}

(Received 16 May 2015; revised 13 January 2016; accepted 17 February 2016;

first published online 6 April 2016)

\section{SUMMARY}

The present study aimed to investigate the effects of adding xylanase enzyme (XY) to a basal diet containing $300 \mathrm{~g}$ maize stover and $700 \mathrm{~g}$ concentrate/kg dry matter (DM) on feed intake, ruminal fermentation, total tract and ruminal digestibility, as well as some blood parameters. Four male Rambouillet sheep ( $39 \pm 1 \cdot 8 \mathrm{~kg}$ body weight), with permanent rumen and duodenum cannulae were used in a $4 \times 4$ Latin square design. Sheep were fed a basal diet without xylanase addition (control, XY0), or with the addition of xylanase at 1 (XY1), 3 (XY3) or 6 (XY6) $\mu \mathrm{l} / \mathrm{g}$ of diet DM for 84 days, with four 21-day experimental periods. Feed intake, digestibility and rumen fermentation parameters were determined on days 16-21 in each experimental period, and the apparent ruminal neutral detergent fibre (NDF) digestibility was determined on days 16 and 17 . Treatments XY1 and XY3 increased feed intake, whereas digestibility was increased with XY6. Ruminal NDF digestibility increased when sheep were fed diets treated with xylanase. Ruminal $\mathrm{pH}$, ammonia-N and acetic acid increased with xylanase treated diets. Propionic acid concentration increased with diet $\mathrm{XY} 1$ at $3 \mathrm{~h}$ post-feeding, but after $9 \mathrm{~h}$ post-feeding its concentration decreased in the rumen of sheep fed xylanase treated diets. Xylanase had no effect on blood urea, phosphorus and triglycerides. Addition of xylanase at $6 \mu \mathrm{l} / \mathrm{g} \mathrm{DM}$ in a diet containing $300 \mathrm{~g}$ maize stover and $700 \mathrm{~g}$ concentrate/kg DM and fed to Rambouillet sheep improved feed digestibility and ruminal fermentation without affecting blood parameters.

\section{INTRODUCTION}

Improving feed utilization in ruminant nutrition is one of the most important features that determine farming profitability. Many strategies have been considered to improve feed utilization; including, for example, the use of live yeast (Elghandour et al. 2014), phytogenic extracts (Salem et al. 2014) or fibrolytic enzymes (Valdes et al. 2015).

A large number of commercial enzyme products, either from fungal or bacterial sources, in relatively concentrated and purified forms and containing

* To whom all correspondence should be addressed. Email: asalem70@yahoo.com specific controlled enzyme activities, have been used in livestock feeding (Dean et al. 2013; AbdelAziz et al. 2015). Feeding fibre-degrading enzymes seems to improve feed utilization as well as animal performance (Khattab et al. 2011; Alsersy et al. 2015), but the mode of action remains unclear. Some possible modes of action have been postulated including hydrolysis of dietary fibre before ingestion, synergistic interaction with endogenous microbial enzymes within the rumen (Morgavi et al. 2004), favoured ruminal fermentation (Salem et al. 2013; Rojo et al. 2015), and enhanced ruminal microorganisms attachment and colonization to the plant cell wall (Wang et al. 2001). 
Although some of the reported results on supplementing animal rations with fibrolytic enzymes are encouraging, they are also inconsistent. In some studies, exogenous enzymes improved feeding value and animal performance by enhancing fibre degradation, increasing intake and feed digestion in vitro (Salem et al. 2015a), in situ (Togtokhbayar et al. 2015) and in vivo (Salem et al. 2015b; Morsy et al. 2016). However, in other studies no effects of exogenous enzymes on feed intake and digestion were observed (Elwakeel et al. 2007; Dean et al. 2013). Although the reasons for this discrepancy are unknown, it could be due to differences in enzyme activity, application rate and composition, type of diet fed to the animals, physiological stage of the animal, time of enzyme delivery, ruminal activity and enzyme stability, enzymefeed specificity and the portion of the diet to which enzymes are applied (Dean et al. 2013).

Exogenous enzyme may affect some serum metabolites that reflect the nutritional and health status of animals (Morsy et al. 2016). Xylanase is an exogenous enzyme that may alter ruminal degradation of feeds and change concentrations of fermentation end-products (Lin et al. 1995). Moreover, it may also cause an indirect glucose sparing effect through the pentose-phosphate pathway (Jackson \& Nicolson 2002).

The objective of the present study was to investigate effects of adding an exogenous xylanase enzyme at different application rates on feed intake, ruminal fermentation, total tract and ruminal digestibility, and blood urea, phosphorus and triglyceride concentrations in Rambouillet sheep fed a basal diet with $300 \mathrm{~g}$ maize stover and $700 \mathrm{~g}$ concentrate/kg dry matter (DM).

\section{MATERIALS AND METHODS}

All procedures involved in handling animals during the experimental period were conducted according to the official Mexican standard of animal care (NOM-051-ZOO-1995).

\section{Study location}

The experiment was conducted at the animal metabolic unit and the laboratory of animal nutrition of the Colegio de Postgraduados, Texcoco, Montecillo, Estado de México, México (2240 m a.s.l.). The climate is moderately humid with an average temperature of $15-18{ }^{\circ} \mathrm{C}$ and annual rainfall of $650 \mathrm{~mm}$. The experiment was conducted during the autumn.
Table 1. Ingredients and chemical composition of the basal diet fed to Rambouillet sheep ( $\mathrm{g} / \mathrm{kg}$ dry matter (DM), unless otherwise stated)

\begin{tabular}{lc}
\hline \hline & $\mathrm{g} / \mathrm{kg} \mathrm{DM}$ \\
\hline Ingredients & \\
Ground sorghum grain & 520 \\
Maize stover & 300 \\
Molasses & 80 \\
Soybean meal & 60 \\
Urea & 40 \\
Chemical composition & \\
Dry matter (g/kg fresh matter) & 870 \\
Organic matter & 950 \\
Crude protein & 154 \\
Ether extract & 57 \\
Neutral detergent fibre & 448 \\
Acid detergent fibre & 252 \\
Phosphorus & $4 \cdot 3$ \\
Calcium & $2 \cdot 5$ \\
\hline \hline
\end{tabular}

Enzyme activity

The enzyme product (Xylanase ${ }^{\circledR}$ plus, Dyadic ${ }^{\circledR}$ PLUS, Dyadic International, Inc., Jupiter, FL, USA) was assessed for endoglucanase and xylanase activities as described by Robyt \& Whelan (1972) by catalytic hydrolysis of xylan from oat spelt and determining the released reducing groups using alkaline copper reagent. The product contained $34000-41000$ units of xylanase/g, 12 000-15000 units of $\beta$-glucanase/g and $45000-55000$ units of cellulase/g.

Animals, housing and feeding

Four Rambouillet rams, weighing $39 \pm 1 \cdot 8 \mathrm{~kg}$ body weight (BW) and fitted with permanent cannulae in the rumen $(2.5 \mathrm{~cm}$ internal diameter (i.d.)) and duodenum (T-type $0.8 \mathrm{~cm}$ i.d.) were used. The sheep were housed in individual cages equipped with high flow valve steel water bowls and fed a basal diet composed of $300 \mathrm{~g}$ maize stover and $700 \mathrm{~g}$ concentrate $/ \mathrm{kg}$ DM (Table 1) ad libitum for 84 days. The basal diet was balanced for minerals and vitamins and formulated to match the nutrient requirements of sheep according to NRC (1985) recommendations plus a margin of $0 \cdot 10$. The ingredients and chemical composition of the basal diet are shown in Table 1. At the beginning of the experiment, sheep were treated with Ivermectin (Ivomec ${ }^{\circledR}-\mathrm{F}-11 \mathrm{ml} / 50 \mathrm{~kg}$ BW, subcutaneous), Bacterin (Covexin ${ }^{\circledR} 10 \mathrm{ml} /$ animal; intramuscular) and vitamins $\mathrm{A}, \mathrm{D}$ and $\mathrm{E}\left(\right.$ Vigantol $^{\circledR} \mathrm{ADE} 1 \mathrm{ml} / \mathrm{animal}$, intramuscular). 
The experiment was laid out according to a $4 \times 4$ Latin square design with four treatments, i.e. four application rates of xylanase $(X Y)$, namely 0 (control, $X Y 0), 1(X Y 1)$, 3 (XY3) and 6 (XY6) $\mu$ l/g DM of the basal diet. In the first experimental period, treatments were assigned randomly to the experimental units (sheep). Experimental periods consisted of 21 days with days $1-15$ considered as the adaptation period to the experimental diets and days 16-21 as the measurement and sample collection period. Sheep were fed twice daily in two equal meals at 07.00 and $19.00 \mathrm{~h}$. The enzyme was added at the corresponding application rate, mixed with the diet individually and fed at $07.00 \mathrm{~h}$. During the collection period, i.e. days 16-21, the amount of feed offered was recorded and orts collected and weighed for determination of daily feed intake. Additionally, feeds were sampled daily, composited weekly, dried at $60{ }^{\circ} \mathrm{C}$ to constant weight and stored for later chemical analysis.

\section{Feed digestibility}

Total tract digestibility was determined by total faecal collection during days 16-21 of each period. Faeces were collected daily before the morning feeding and stored at $-10^{\circ} \mathrm{C}$ for later analysis. A sub-sample of about 100 $\mathrm{g} / \mathrm{kg}$ of the total faeces collected from each sheep was taken daily and composited for chemical analysis.

Apparent ruminal fibre digestibility was determined on days 16 and 17 following the procedure of Kozloski et al. (2014). Duodenal digesta samples (approximately $50 \mathrm{ml}$ ) were collected from each sheep 4 $\mathrm{h}$ after morning feeding and then at $4 \mathrm{~h}$ intervals over a period of $48 \mathrm{~h}$. Samples were obtained from the duodenal cannula, collected in a $100 \mathrm{ml}$ amber vial and immediately frozen until analysis. Samples were subsequently thawed and dried at $55^{\circ} \mathrm{C}$ for $48 \mathrm{~h}$, homogenized and analysed for neutral detergent fibre (NDF) and acid detergent fibre (ADF).

Dried feed, feed orts and faecal samples were ground through a Wiley mill (Arthur $\mathrm{H}$. Thomas, Philadelphia, PA, USA) using a $1 \mathrm{~mm}$ screen and analysed according to AOAC (1997) for DM (\#930-15), ash (\#942.05), ether extract (EE; \#920·39), nitrogen $(\mathrm{N} ; \# 954 \cdot 01)$ and ADF (\#973.18), while NDF was analysed according to Van Soest et al. (1991). Organic matter (OM, g/kg DM) content was calculated by difference (1000-g ash/kg DM).

\section{Rumen and blood sampling and analysis}

Rumen fluid was collected on day 18 of each experimental period, directly through the rumen cannula from the ventral sac of each sheep at 3, 6 and $9 \mathrm{~h}$ after morning feeding. The rumen samples (approximately $50 \mathrm{ml} / \mathrm{sheep)}$ were filtered immediately through four layers of cheesecloth, strained and stored in $45 \mathrm{ml}$ glass bottles. Ruminal fluid $\mathrm{pH}$ was then determined using a portable $\mathrm{pH}$ meter (Orion, model SA 210, USA). Subsequently, $4 \mathrm{ml}$ of rumen fluid was mixed with $1 \mathrm{ml}$ of a solution of metaphosphoric acid $(250 \mathrm{~g} / \mathrm{l})$ in a test tube and stored at $-18{ }^{\circ} \mathrm{C}$ for subsequent volatile fatty acid (VFA) analysis. A sub-sample of $5 \mathrm{ml}$ of rumen fluid was acidified with $5 \mathrm{ml}$ of $0 \cdot 2 \mathrm{M}$ hydrochloric acid $(\mathrm{HCl})$ for ammonia- $\mathrm{N}$ analysis.

Concentrations of acetic, propionic and butyric acids in rumen fluid were measured by gas-liquid chromatography (Hewlett Packard, Little Falls, DE, USA) using a capillary column (30 m length, 0.32 $\mathrm{mm}$ i.d., $0 \cdot 25 \mathrm{~mm}$ film thickness; Elite-FFAP, Perkin Elmer Instruments, Shelton, WA, USA) according to the method of Erwin et al. (1961). The injector temperature was set at $240{ }^{\circ} \mathrm{C}$, flame ionization detector at $250^{\circ} \mathrm{C}$ and oven at $140{ }^{\circ} \mathrm{C}$ with hydrogen gas $\left(\mathrm{H}_{2}\right)$ and air flows at 40 and $400 \mathrm{ml} / \mathrm{min}$, respectively.

Concentrations of ammonia- $\mathrm{N}$ were determined photometrically in an ultraviolet light spectrophotometer (VARIAN CARY 1-E, CA, USA) set at a wavelength of $630 \mathrm{~nm}$ according to McCullough (1967).

On day 21 of each experimental period and $4 \mathrm{~h}$ after morning feeding, a sample of $10 \mathrm{ml}$ of blood was collected via jugular vein of each sheep into clean dry test tubes, without anticoagulant. Blood samples were centrifuged at $5000 \mathrm{~g}$ at $4{ }^{\circ} \mathrm{C}$ for $20 \mathrm{~min}$. Serum was separated into $2 \mathrm{ml}$ Eppendorf tubes and frozen at $-20^{\circ} \mathrm{C}$ until analysis. Blood serum samples were analysed for concentrations of urea, phosphorus and triglycerides using specific kits (Stanbio Laboratory, Boerne, TX, USA) according to the manufacturer's specifications.

\section{Statistical analysis}

Data on feed intake, digestibility, ruminal fermentation parameters (at each time post-feeding) and blood parameters were examined by analysis of variance according to a $4 \times 4$ Latin square design with four periods and four experimental diets (XYO, XY1, $X Y 3, X Y 6)$ using PROC MIXED of SAS (SAS Institute 2006). One ram was used within each period and treatment. The statistical model was:

$$
Y_{i j k l}=m+A_{i}+P_{j}+T_{k}+\varepsilon_{i j k l}
$$

where $Y_{i j k l}$ is the observation for a given response variable, $\mu$ is the overall mean, $A_{i}$ is the random effect of 
Table 2. Feed intake, digestibility and blood metabolites in Rambouillet sheep fed a diet treated with increasing concentrations of xylanase $(X Y)$

\begin{tabular}{|c|c|c|c|c|c|c|c|c|c|c|}
\hline & \multicolumn{4}{|c|}{ Diets* } & \multirow[b]{2}{*}{ S.E.M. $(n=4)$} & \multicolumn{4}{|c|}{$P$ value } & \multirow[b]{2}{*}{ Cubic } \\
\hline & XYO & $\mathrm{XY} 1$ & $\mathrm{XY} 3$ & XY6 & & $\begin{array}{l}\text { Treatment } \\
\text { effect }\end{array}$ & $\begin{array}{l}\text { Control } v \text {. } \\
\text { enzyme }\end{array}$ & Linear & Quadratic & \\
\hline Feed intake (g DM/d) & 1146 & 1211 & 1180 & 1004 & $56 \cdot 2$ & $0 \cdot 043$ & $0 \cdot 034$ & $0 \cdot 066$ & $0 \cdot 508$ & $0 \cdot 684$ \\
\hline \multicolumn{11}{|c|}{ Total tract digestibility (g digested/g ingested) } \\
\hline Dry matter & $0 \cdot 58$ & $0 \cdot 60$ & $0 \cdot 57$ & $0 \cdot 75$ & $0 \cdot 041$ & $0 \cdot 047$ & $0 \cdot 027$ & $0 \cdot 021$ & $0 \cdot 014$ & $0 \cdot 901$ \\
\hline Organic matter & $0 \cdot 59$ & $0 \cdot 62$ & $0 \cdot 59$ & $0 \cdot 77$ & $0 \cdot 039$ & $0 \cdot 032$ & $0 \cdot 019$ & $0 \cdot 018$ & $0 \cdot 014$ & $1 \cdot 000$ \\
\hline Crude protein & $0 \cdot 54$ & $0 \cdot 56$ & $0 \cdot 51$ & $0 \cdot 71$ & 0.053 & $0 \cdot 036$ & $0 \cdot 044$ & $0 \cdot 069$ & $0 \cdot 015$ & $0 \cdot 702$ \\
\hline Neutral detergent fibre & $0 \cdot 56$ & $0 \cdot 59$ & $0 \cdot 61$ & $0 \cdot 76$ & $0 \cdot 039$ & 0.037 & 0.077 & $0 \cdot 008$ & $0 \cdot 078$ & $0 \cdot 078$ \\
\hline Acid detergent fibre & $0 \cdot 46$ & $0 \cdot 50$ & $0 \cdot 53$ & $0 \cdot 70$ & $0 \cdot 051$ & $0 \cdot 006$ & $0 \cdot 020$ & $0 \cdot 031$ & $0 \cdot 243$ & $0 \cdot 305$ \\
\hline \multicolumn{11}{|c|}{ Apparent ruminal digestibility (g digested/g ingested) } \\
\hline Neutral detergent fibre & $0 \cdot 36$ & $0 \cdot 39$ & $0 \cdot 42$ & $0 \cdot 46$ & $0 \cdot 024$ & $0 \cdot 045$ & $0 \cdot 036$ & $0 \cdot 122$ & $0 \cdot 078$ & $0 \cdot 078$ \\
\hline Acid detergent fibre & $0 \cdot 29$ & $0 \cdot 31$ & $0 \cdot 33$ & $0 \cdot 34$ & $0 \cdot 022$ & $0 \cdot 055$ & $0 \cdot 584$ & $0 \cdot 294$ & $0 \cdot 050$ & $0 \cdot 305$ \\
\hline \multicolumn{11}{|c|}{ Blood metabolites $(\mathrm{mg} / \mathrm{dl})$} \\
\hline Urea & 44 & 49 & 50 & 49 & $4 \cdot 4$ & $0 \cdot 358$ & $0 \cdot 643$ & $0 \cdot 346$ & $0 \cdot 147$ & $0 \cdot 355$ \\
\hline Phosphorus & $0 \cdot 23$ & $0 \cdot 29$ & $0 \cdot 27$ & $0 \cdot 22$ & 0.098 & 0.574 & $0 \cdot 431$ & $0 \cdot 233$ & 0.699 & $0 \cdot 808$ \\
\hline Triglycerides & 8 & 10 & 6 & 9 & $2 \cdot 0$ & $0 \cdot 511$ & 0.945 & $0 \cdot 917$ & $0 \cdot 339$ & $0 \cdot 369$ \\
\hline
\end{tabular}

DM, dry matter. *Diet (Table 1) without addition of xylanase (XY0) or with addition of xylanase at 1 (XY1), 3 (XY3) and 6 (XY6) $\mu \mathrm{l} / \mathrm{g} \mathrm{DM}$.

ram, $P_{j}$ is the fixed effect of period, $T_{k}$ is the fixed effect of rate of addition of enzyme (XY0, XY1, XY3, XY6) and $\varepsilon_{i j k l}$ is the residual error. Tukey's test was used for multiple comparisons of means. Polynomial contrasts (linear, quadratic and cubic effects) were fitted to the four rates of addition of the enzyme. A treatment (average of all treatments receiving XY) $\mathrm{v}$. control contrast was also performed. Significance was declared at a level of $P<0.05$ and $P \leqslant 0.10$ was considered as a tendency approaching significance.

\section{RESULTS}

Feed intake, digestibility and blood parameters

Sheep fed XY1 and XY3 had greater $(P=0.035)$ feed $D M$ intake than the control sheep (increases of 6 and $3 \%$ with $\mathrm{XY} 1$ and $\mathrm{XY} 3$, respectively). However, at the greatest application rate (XY6) feed intake was decreased slightly when compared with the control.

Sheep fed $\mathrm{XY} 1$ and $\mathrm{XY} 6$ had greater $(P<0 \cdot 05)$ total tract $\mathrm{DM}, \mathrm{OM}$ and crude protein $(\mathrm{CP})$ digestibility than the control sheep. Dry matter digestibility increased by $30 \%$ with XY6 when compared with the control diet. Digestibility of ADF increased linearly $(P=0.008)$ with increasing enzyme application rates. The NDF digestibility of the enzyme treated diets tended $(P=0.077)$ to be greater than that of the control sheep (Table 2).
Sheep fed enzyme had greater $(P<0.036)$ ruminal NDF digestibility than control sheep. With XY6, ruminal NDF digestibility was increased by $28 \%$ when compared with the control diet. There was no difference in ruminal ADF digestibility between sheep fed the enzyme and the control diet (Table 2).

There were no differences in the blood concentrations of urea, phosphorus or triglycerides due to the different levels of xylanase addition (Table 2).

\section{Ruminal fermentation}

Ruminal $\mathrm{pH}$ of sheep fed with the enzyme was greater at all sampling times ( $P$ values were 0.050, 0.020 and 0.033 at 3, 6 and $9 \mathrm{~h}$ post-feeding, respectively) compared with control sheep. Within enzyme treatment, at the $3 \mathrm{~h}$ sampling, increasing enzyme application rate had no effect on $\mathrm{pH}$. Sheep fed $\mathrm{XY} 1$ had maximum $\mathrm{pH}$ at the $6 \mathrm{~h}$ sampling and minimum $\mathrm{pH}$ at the $9 \mathrm{~h}$ sampling.

At the $6 \mathrm{~h}$ sampling, the ruminal ammonia- $\mathrm{N}$ concentration of sheep fed enzyme-treated diets was greater $(P=0 \cdot 048)$ than the control sheep. Within enzyme treatment, XY6 showed the maximum ammonia concentrations (linear effect, $P=0.028$ ), with an increase of $90 \%$ over the control value. At the 3 and $9 \mathrm{~h}$ sampling, there were no differences. 
Table 3. Rumen fermentation at different times post-feeding of a diet treated with increasing concentrations of xylanase (XY) in Rambouillet sheep

\begin{tabular}{|c|c|c|c|c|c|c|c|c|c|}
\hline & \multicolumn{4}{|c|}{ Diets* } & \multirow[b]{2}{*}{ S.E.M. $(n=4)$} & \multicolumn{4}{|c|}{$P$ value } \\
\hline & XYO & $\mathrm{XY} 1$ & $\mathrm{XY} 3$ & XY6 & & $\begin{array}{l}\text { Treatment } \\
\text { effect }\end{array}$ & $\begin{array}{l}\text { Control } v \text {. } \\
\text { enzyme }\end{array}$ & Linear & Quadratic \\
\hline \multicolumn{10}{|l|}{$\mathrm{pH}$} \\
\hline $3 \mathrm{~h}$ & $6 \cdot 0$ & $6 \cdot 3$ & $6 \cdot 2$ & $5 \cdot 8$ & $0 \cdot 17$ & $0 \cdot 031$ & $0 \cdot 050$ & $0 \cdot 198$ & $0 \cdot 385$ \\
\hline $6 \mathrm{~h}$ & $5 \cdot 8$ & $6 \cdot 1$ & $6 \cdot 0$ & $6 \cdot 1$ & $0 \cdot 13$ & $0 \cdot 057$ & $0 \cdot 020$ & $0 \cdot 041$ & $0 \cdot 051$ \\
\hline $9 \mathrm{~h}$ & $5 \cdot 8$ & $5 \cdot 9$ & $6 \cdot 0$ & $6 \cdot 0$ & 0.06 & $0 \cdot 116$ & $0 \cdot 033$ & $0 \cdot 039$ & $0 \cdot 236$ \\
\hline \multicolumn{10}{|c|}{ Ammonia-N (mmol/l) } \\
\hline $3 \mathrm{~h}$ & $17 \cdot 3$ & $15 \cdot 9$ & $15 \cdot 5$ & $16 \cdot 6$ & $3 \cdot 11$ & 0.976 & $0 \cdot 730$ & 0.933 & $0 \cdot 690$ \\
\hline $6 \mathrm{~h}$ & $7 \cdot 7$ & $9 \cdot 0$ & $12 \cdot 7$ & $14 \cdot 6$ & $1 \cdot 86$ & $0 \cdot 012$ & $0 \cdot 048$ & $0 \cdot 028$ & 0.929 \\
\hline $9 \mathrm{~h}$ & $8 \cdot 6$ & $8 \cdot 3$ & $8 \cdot 2$ & $8 \cdot 2$ & $0 \cdot 43$ & $0 \cdot 906$ & $0 \cdot 517$ & $0 \cdot 604$ & 0.650 \\
\hline \multicolumn{10}{|c|}{ Acetic acid (mmol/l) } \\
\hline $3 \mathrm{~h}$ & $44 \cdot 7$ & $47 \cdot 5$ & $51 \cdot 9$ & $48 \cdot 0$ & $3 \cdot 32$ & $0 \cdot 054$ & $0 \cdot 029$ & $0 \cdot 889$ & $0 \cdot 058$ \\
\hline $6 \mathrm{~h}$ & $46 \cdot 0$ & $45 \cdot 2$ & $51 \cdot 3$ & $59 \cdot 3$ & $4 \cdot 39$ & $0 \cdot 019$ & $0 \cdot 029$ & $0 \cdot 105$ & $0 \cdot 330$ \\
\hline $9 \mathrm{~h}$ & $46 \cdot 0$ & $45 \cdot 3$ & $45 \cdot 9$ & $45 \cdot 2$ & $1 \cdot 45$ & $0 \cdot 967$ & $0 \cdot 740$ & $0 \cdot 763$ & $0 \cdot 948$ \\
\hline \multicolumn{10}{|c|}{ Propionic acid (mmol/l) } \\
\hline $3 \mathrm{~h}$ & $43 \cdot 2$ & $47 \cdot 3$ & $45 \cdot 0$ & $42 \cdot 3$ & $1 \cdot 91$ & $0 \cdot 035$ & $0 \cdot 047$ & $0 \cdot 379$ & $0 \cdot 026$ \\
\hline $6 \mathrm{~h}$ & $42 \cdot 7$ & $42 \cdot 9$ & $39 \cdot 1$ & $45 \cdot 7$ & $2 \cdot 75$ & $0 \cdot 047$ & $0 \cdot 046$ & $0 \cdot 530$ & $0 \cdot 213$ \\
\hline $9 \mathrm{~h}$ & $47 \cdot 5$ & $45 \cdot 7$ & $44 \cdot 2$ & $45 \cdot 9$ & $2 \cdot 19$ & $0 \cdot 047$ & $0 \cdot 041$ & 0.672 & 0.037 \\
\hline \multicolumn{10}{|c|}{ Butyric acid (mmol/l) } \\
\hline $3 \mathrm{~h}$ & $13 \cdot 3$ & $13 \cdot 7$ & $13 \cdot 2$ & $13 \cdot 3$ & $0 \cdot 19$ & $0 \cdot 340$ & $0 \cdot 631$ & $0 \cdot 584$ & $0 \cdot 871$ \\
\hline $6 \mathrm{~h}$ & $12 \cdot 6$ & $12 \cdot 9$ & $13 \cdot 1$ & $13 \cdot 1$ & $0 \cdot 41$ & 0.078 & $0 \cdot 374$ & 0.426 & 0.571 \\
\hline $9 \mathrm{~h}$ & $13 \cdot 3$ & $12 \cdot 0$ & $12 \cdot 9$ & $12 \cdot 9$ & $0 \cdot 40$ & $0 \cdot 228$ & $0 \cdot 175$ & $0 \cdot 842$ & $0 \cdot 372$ \\
\hline
\end{tabular}

*Diet (Table 1) without addition of xylanase (XY0) or with addition of xylanase at 1 (XY1), 3 (XY3) and 6 (XY6) $\mu$ l/g DM.

Acetic acid concentrations $(\mathrm{mmol} / \mathrm{l})$ were greater (quadratic effect, $P=0.029$ ) in enzyme treatments compared with the control at 3 and 6 h post-feeding. With XY 6 these concentrations were increased by 7 and $28 \%$ compared with the control at 3 and $6 \mathrm{~h}$ post-feeding, respectively. At $9 \mathrm{~h}$, there were no significant differences. Propionic acid concentrations $(\mathrm{mmol} / \mathrm{l})$ at $3 \mathrm{~h}$ post-feeding were greatest in $\mathrm{XY} 1$ (quadratic effect, $P=0.026$ ); however, at the $9 \mathrm{~h}$ sampling, all enzyme treatments had lower $(P=0 \cdot 041)$ propionic acid concentrations compared with the control. Among enzyme application rates, XY3 had the lowest propionic acid concentration (quadratic effect, $P=0.037$ ). No effects were observed on ruminal butyric acid concentrations between different treatments at all sampling times (Table 3).

\section{DISCUSSION}

Feed intake

Addition of xylanase to diets at low (i.e. $\mathrm{XY} 1$ ) and moderate (i.e. $\mathrm{XY}$ ) rates increased feed intake by about 6 and 3\%, respectively, compared with XY0; however, intake decreased by $9 \%$ when xylanase was applied at a greater concentration (i.e. XY6) compared with XYO. Therefore, addition of fibrolytic enzymes at certain concentrations may increase the intake of fibrous feeds. Beauchemin et al. (2003) concluded that high rates of enzyme application could be less effective than low rates of application in increasing feed intake, indicating the importance of determining the optimal rate of enzyme addition. The current results are in agreement with Gado et al. (2009), who observed about $13 \%$ greater DM intake in dairy cows due to enzyme supplementation at $40 \mathrm{~g}$ /day.

\section{Digestibility}

When xylanase was applied to the diet at the highest concentration (i.e. XY6), whole tract digestibility was increased (by 28-42\%) compared with other xylanase concentrations. Improving digestibility, in particular, that of the fibre fractions is the main purpose of adding fibrolytic enzymes to ruminant feeds. Improved digestibility with xylanase at some 
application rates supports the hypothesis that a suitable enzyme concentration could improve fermentation efficiency during the initial stages of digestion (Jalilvand et al. 2008).

The greater digestibility observed with the XY 6 diet may be related, as previously mentioned, to improved rate of ruminal digestion of the potentially digestible NDF fraction (Yang et al. 1999) and to changes in gut viscosity (Hristov et al. 2000); although these features were not determined in the present study. Altered ruminal fermentation (Kholif \& Aziz 2014; Rojo et al. 2015), enhanced microbial attachment and colonization to the plant cell wall (Wang et al. 2001) and complementary interactions with ruminal microbial enzymes (Morgavi et al. 2004) are different possible reasons for the improved rate of ruminal digestion.

In most reports, addition of fibrolytic enzymes to the ruminant feedstuffs increased the numbers of nonfibrolytic and fibrolytic bacteria in rumen fluid and provided more total polysaccharidase activity to digest feedstuffs (Giraldo et al. 2008). Mao et al. (2013) found that addition of cellulase and xylanase increased the numbers of total bacteria and Fibrobacter succinogenes in in vitro incubation medium resulting in enhanced fermentation. Results in the present study are consistent with Khattab et al. (2011) and Salem et al. (2013; 2015b), who observed greater feed digestibility in response to exogenous enzyme addition.

Ruminal NDF digestibility was increased by $7 \cdot 5,17$ and $28 \%$ (compared with the control diet), respectively, with increasing xylanase application rates. Thus, the increased total tract fibre digestibility seems to be due, in part, to enhance fibre digestion in the rumen. Fibrolytic enzymes not only improve fibrolytic activity in the rumen, but also raise xylanase activity in the small intestine (Hristov et al. 1998, 2000). Hristov et al. (1998) reported that addition of enzymes elevated duodenal xylanase activity by $30 \%$ and cellulase activity by $2-5 \%$. Hristov et al. (2000) showed that xylanase activity in the faeces was increased with enzyme supplementation, suggesting that xylanase and probably other exogenous fibrolytic enzymes, may work synergistically with the microbes within the large intestine.

\section{Blood metabolites}

None of the measured blood metabolites (urea, phosphorus and triglycerides) was affected by xylanase addition to feed and all were found within the reference ranges (Boyd 1984). Serum urea concentration is an indicator of the nutritional status of sheep (Kumar et al. 1981), in particular regarding the provision of total and degradable protein in the feed. Normal serum urea values indicate that protein catabolism was not increased in the muscles and that kidney function was not adversely affected by diet.

\section{Ruminal fermentation}

Sheep fed xylanase had greater ruminal $\mathrm{pH}$ values compared with the control. One of the most important factors affecting fibre digestion is ruminal $\mathrm{pH}$. For xylanase treatments, rumen $\mathrm{pH}$ ranged from 5.98 to $6 \cdot 15$, which was within the range considered acceptable for fibre digestion (Ørskov \& Ryle 1990). Fibrolytic bacteria are very sensitive to ruminal $\mathrm{pH}$ changes (Sung et al. 2007). Greater ruminal $\mathrm{pH}$ values are more favourable for fibrolytic microbial activity than low ruminal pH (Sung et al. 2007).

Ruminal ammonia- $\mathrm{N}$ concentrations ranged from $7 \cdot 7$ to $17.3 \mathrm{mmol} / \mathrm{l}$ which were above the range that Satter \& Slyter (1974) considered as sufficient for microbial protein synthesis. Greater ruminal ammonia- $\mathrm{N}$ concentrations in sheep fed the enzyme treated diets (XY6 and $X Y 3)$ compared with the un-supplemented control support the possibility that xylanase enhances rumen protein degradation, probably in response to a shift in ruminal microbiota (Salem et al. 2013). Kholif \& Aziz (2014) found that feeding goats on diets treated with a fibrolytic enzyme elevated ruminal ammonia- $\mathrm{N}$ concentration compared with un-supplemented control diets. The observed dose-effects reinforce the importance of defining the optimum application rate of enzyme for better feed utilization.

Greater acetic acid concentrations were obtained with xylanase-treated diets (especially with XY6) compared with the control. Improving fibre digestion usually alters rumen fermentation and affects the production of individual VFA. The greater acetic acid concentrations with xylanase addition could be associated with improved digestion of structural carbohydrates (Soltan et al. 2013). Changes in individual VFA concentrations observed when fibrolytic enzymes were added to feed suggest that these exogenous enzymes could affect microbial growth and activity, causing a shift in the metabolic pathways by which specific microbes utilize substrates (Almaraz et al. 2010). Shifts in ruminal fermentation may be the result of altered fibre structure, which could stimulate microbial colonization (Giraldo et al. 2008), or a 
shift in the species profile of fibre-colonizing bacteria in response to enzyme addition (Wang et al. 2001). Gado et al. (2009) and Salem et al. (2013) also observed greater acetic acid concentrations in the rumen when animals were fed diets supplemented with exogenous enzymes.

Among the tested xylanase application rates, concentrations of 3 and $6 \mu \mathrm{l}$ xylanase/g DM of the basal diet resulted in enhanced digestibility and ruminal fermentation in Rambouillet sheep. However, with $6 \mu \mathrm{l}$ xylanase/g DM of the basal diet feed intake decreased, whereas ruminal ammonia- $\mathrm{N}$ and individual VFA increased compared with the other rates of enzyme addition. Generally, addition of xylanase had no effects on blood serum concentrations of urea, phosphorus and triglycerides.

The authors acknowledge the financial support from the IAEA (Vienna, Austria) Research Contract number MEX16307 within the D3·10.27 Coordinated Research Project. First author would like to thank the Mexican National Council for Science and Technology (Consejo Nacional de Ciencia y Tecnología-CONACYT) for the PhD scholarship received.

\section{REFERENCES}

Abdel-Aziz, N. A., Salem, A.Z.M., El-Adawy, M.M., Camacho, L.M., Kholif, A. E., Elghandour, M. M. Y. \& Borhami, B. E. (2015). Biological treatments as a mean to improve feed utilization in agriculture animals - an overview. Journal of Integrative Agriculture 14, 534-543.

Almaraz, I., González, S.S., Pinos-Rodríguez, J.M. \& MiRANDA, L.A. (2010). Effects of exogenous fibrolytic enzymes on in sacco and in vitro degradation of diets and on growth performance. Italian Journal of Animal Science 9, 6-10.

Alsersy, H., Salem, A.Z.M., Borhami, B. E., Olivares, J., Gado, H.M., Mariezcurrena, M.D., Yacuot, M.H., Kholif, A. E., El-Adawy, M. \& Hernandez, S. R. (2015). Effect of Mediterranean saltbush (Atriplex halimus) ensilaging with two developed enzyme cocktails on feed intake, nutrient digestibility and ruminal fermentation in sheep. Animal Science Journal 86, 51-58.

AOAC (1997). Official Methods of Analysis of the Association of Official Analytical Chemist, Vol. 1, 16th edn, Washington, DC: Association of Official Analytical Chemists.

Beauchemin, K.A., Colombatto, D., Morgavi, D.P. \& YANG, Y. Z. (2003). Use of exogenous fibrolytic enzymes to improve feed utilization by ruminants. Journal of Animal Science 81, (E Suppl.) 2, E37-E47.
Boyd, J. W. (1984). The interpretation of serum biochemistry test results in domestic animals. Veterinary Clinical Pathology 13, 7-14.

Dean, D. B., Staples, C. R., Littell, R. C., Kim, S. C. \& Adesogan, A. T. (2013). Effect of method of adding a fibrolytic enzyme to dairy cow diets on feed intake digestibility, milk production, ruminal fermentation, and blood metabolites. Animal Nutrition and Feed Technology 13, 337-353.

Elghandour, M. M. Y., Vázquez Chagoyán, J. C., Salem, A. Z. M., Kholif, A. E., Martínez Castañeda, J. S., Camacho, L. M. \& Cerrillo-Soto, M. A. (2014). Effects of Saccharomyces cerevisiae at direct addition or pre-incubation on in vitro gas production kinetics and degradability of four fibrous feeds. Italian Journal of Animal Science 13, 295-301.

Elwakeel, E. A., Titgemeyer, E. C., Johnson, B.J., Armendariz, C. K. \& ShiRley, J.E. (2007). Fibrolytic enzymes to increase the nutritive value of dairy feedstuffs. Journal of Dairy Science 90, 5226-5236.

Erwin, E. S., Marco, G. J. \& Emerr, E. M. (1961). Volatile fatty acid analysis of blood and rumen fluid by gas chromatography. Journal of Dairy Science 44, 1768-1771.

Gado, H. M., Salem, A. Z. M., Robinson, P. H. \& Hassan, M. (2009). Influence of exogenous enzymes on nutrient digestibility, extent of ruminal fermentation as well as milk production and composition in dairy cows. Animal Feed Science and Technology 154, 36-46.

Giraldo, L.A., Tejido, M.L., Ranilla, M.J., Ramos, S. \& CARRO, M. D. (2008). Influence of direct-fed fibrolytic enzymes on diet digestibility and ruminal activity in sheep fed a grass hay-based diet. Journal of Animal Science 86, 1617-1623.

Hristov, A. N., McAllister, T.A. \& Cheng, K.-J. (1998). Stability of exogenous polysaccharide-degrading enzymes in the rumen. Animal Feed Science and Technology 76, 161-168.

Hristov, A. N., McAllister, T. A. \& ChenG, K.-J. (2000). Intraruminal supplementation with increasing levels of exogenous polysaccharide-degrading enzymes: effects on nutrient digestion in cattle fed a barley grain diet. Journal of Animal Science 78, 477-487.

JACKSON, S. \& NiCOlson, S.W. (2002). Xylose as a nectar sugar: from biochemistry to ecology. Comparative Biochemistry and Physiology Part B. Biochemistry and Molecular Biology 131, 613-620.

Jalilvand, G., Odongo, N.E., Lopez, S., Naserian, A., Valizadeh, R., Shahrodi, E., Kebreab, E., France, J. (2008). Effects of different levels of an enzyme mixture on in vitro gas production parameters of contrasting forages. Animal Feed Science and Technology 146, 289-301.

Khattab, H. M., Gado, H. M., Kholif, A. E., Mansour, A. M. \& KHOLIF, A. M. (2011). The potential of feeding goats sun dried rumen contents with or without bacterial inoculums as replacement for berseem clover and the effects on milk production and animal health. International Journal of Dairy Science 6, 267-277.

Kholif, A. E., Gouda, G. A., Morsy, T.A., Salem, A. Z. M., Lopez, S. \& Kholif, A. M. (2015). Moringa oleifera leaf meal as a protein source in lactating goat's diets: feed intake, digestibility, ruminal fermentation, milk yield and 
composition, and its fatty acids profile. Small Ruminant Research 129, 129-137.

Kholif, A. M. \& AzIz, H. A. (2014). Influence of feeding cellulytic enzymes on performance, digestibility and ruminal fermentation in goats. Animal Nutrition and Feed Technology 14, 121-136.

Kozloski, G. V., Stefanello, C. M., Mesquita, F. R., Alves, T. P., Ribeiro Filho, H.M. N., Almeida, J. G. R. \& Moraes GenRo, T.C. (2014). Technical note: evaluation of markers for estimating duodenal digesta flow and ruminal digestibility: acid detergent fiber, sulfuric acid detergent lignin, and n-alkanes. Journal of Dairy Science 97, 1730-1735.

Kumar, N., Singh, U. B. \& Verma, D. N. (1981). Effect of different levels of dietary protein and energy on growth of male buffalo calves. Indian Journal of Animal Science 51, 513-517.

Lin, Y., Vonk, R. J., Slooff, M. J. H., Kuipers, F. \& Smit, M. J. (1995). Differences in propionate-induced inhibition of cholesterol and triacylglycerol synthesis between human and rat hepatocytes in primary culture. British Journal of Nutrition 74, 197-207.

MaO, H. L., Wu, C. H., Wang, J.K. \& Liu, J. X. (2013). Synergistic effect of cellulase and xylanase on in vitro rumen fermentation and microbial population with rice straw as substrate. Animal Nutrition and Feed Technology 13, 477-487.

McCullough, H. (1967). The determination of ammonia in whole blood by direct colorimetric method. Clinica Chimica Acta 17, 297-304.

Morgavi, D. P., Beauchemin, K. A., Nsereko, V. L., Rode, L. M., McAllister, T.A. \& WANG, Y. (2004). Trichoderma enzymes promote Fibrobacter succinogenes S85 adhesion to, and degradation of, complex substrates but not pure cellulose. Journal of the Science of Food and Agriculture 84, 1083-1090.

Morsy, T.A., Kholif, A. E., Kholif, S. M., Kholif, A. M., Sun, X. \& Salem, A. Z. M. (2016). Effects of two enzyme feed additives on digestion and milk production in lactating Egyptian buffaloes. Annals of Animal Science 16, 209222.

NRC (1985). Nutrient Requirements of Sheep, 6th edn, Washington, DC: National Academy Press.

ØrSkOV, E. R. \& RYLE, R. (1990). Energy Nutrition in Ruminants. New York: Elsevier Science Publishers.

RobYt, J. F. \& WHELAN, W. J. (1972). Reducing value methods for maltodextrins. 1. Chain-length dependence of alkaline 3,5-dinitrosalicylate and chain length independence of alkaline copper. Analytical Biochemistry 45, 510-516.

Rojo, R., Kholif, A. E., Salem, A. Z. M., Elghandour, M. M. Y., Odongo, N. E., Montes De Oca, R., Rivero, N. \& AlONSO, M. U. (2015). Influence of cellulase addition to dairy goat diets on digestion and fermentation, milk production and fatty acid content. Journal of Agricultural Science, Cambridge 153, 1514-1523.

Salem, A.Z.M., Gado, H.M., Colombatto, D. \& Elghandour, M.M. Y. (2013). Effects of exogenous enzymes on nutrient digestibility, ruminal fermentation and growth performance in beef steers. Livestock Science 154, 69-73.
Salem, A.Z.M., Kholif, A. E., Elghandour, M.M. Y., Buendía, G., Mariezcurrena, M. D., Hernandez, S. R. \& CAMACHO, L. M. (2014). Influence of oral administration of Salix babylonica extract on milk production and composition in dairy cows. Italian Journal of Animal Science 13, 10-14.

Salem, A. Z. M., Ammar, H., Kholif, A. E., Elghandour, M. M. Y. \& OrTIZ, L. B. (2015a). Effect of glucoamylase enzyme extract on in vitro gas production and degradability of two diets with $25 \%$ of corn or sorghum grains. Indian Journal of Animal Science 85, 183-188.

Salem, A. Z. M., Alsersy, H., Camacho, L. M., El-Adawy, M. M., Elghandour, M.M.Y., Kholif, A. E., Rivero, N., Alonso, M. U. \& Zaragoza, A. (2015b). Feed intake, nutrient digestibility, nitrogen utilization, and ruminal fermentation activities in sheep fed Atriplex halimus ensiled with three developed enzyme cocktails. Czech Journal of Animal Science 60, 185-194.

SAS Institute (2006). SAS 9.0 User's Guide: Statistics, version 9.0. Cary, NC: SAS Institute.

SAtTer, L. D. \& Slyter, L. L. (1974). Effect of ammonia concentration on rumen microbial protein production in vitro. British Journal of Nutrition 32, 199-208.

Soltan, Y. A., Abdalla, A. L., Silva, L. R. F., Natel, A. S., Morsy, A.S. \& LouvandinI, H. (2013). Response of different tropical pasture grass species to treatments with fibrolytic enzymes in terms of in vitro ruminal nutrient degradation and methanogenesis. Animal Nutrition and Feed Technology 13, 551-568.

Sung, H. G., Kobayashi, Y., Chang, J., Ha, A., Hwang, I. H. \& $\mathrm{HA}_{\mathrm{A}}$ J. K. (2007). Low ruminal $\mathrm{pH}$ reduces dietary fiber digestion via reduced microbial attachment. AsianAustralasian Journal of Animal Sciences 20, 200-207.

Togtokhbayar, N., Cerrillo, M. A., Rodríguez, G. B., Elghandour, M.M.M.Y., Salem, A.Z.M., Urankhaich, C., Jigjidpurev, S., Odongo, N.E. \& KHOLIF, A. E. (2015). Effect of exogenous xylanase on rumen in vitro gas production and degradability of wheat straw. Animal Science Journal 86, 765-771.

Valdes, K.I., Salem, A.Z.M., Lopez, S., Alonso, M. U., Rivero, N., Elghandour, M.M.Y., Domínguez, I. A., Ronquillo, M. G. \& Kholif, A. E. (2015). Influence of exogenous enzymes in presence of Salix babylonica extract on digestibility, microbial protein synthesis and performance of lambs fed maize silage. Journal of Agricultural Science, Cambridge 153, 732-742.

Van Soest, P. J., Robertson, J. B. \& Lewis, B. A. (1991). Methods for dietary fibre, neutral detergent fibre, and non-starch carbohydrates in relation to animal nutrition. Journal of Dairy Science 74, 3583-3597.

Wang, Y., McAllister, T. A., Rode, L. M., Beauchemin, K. A., Morgavi, D. P., Nsereko, V. L., IwaAsa, A. D. \& YanG, W. (2001). Effects of an exogenous enzyme preparation on microbial protein synthesis, enzyme activity and attachment to feed in the rumen simulation technique (Rusitec). British Journal of Nutrition 85, 325-332.

Yang, W. Z., Beauchemin, K. A. \& Rode, L. M. (1999). Effects of an enzyme feed additive on extent of digestion and milk production of lactating dairy cows. Journal of Dairy Science 82, 391-403. 